\title{
Power Generation from Human Leukocytes/Lymphocytes in Mammalian Biofuel Cell
}

\author{
Güray Güven, ${ }^{1}$ Pablo Lozano-Sanchez, ${ }^{2}$ and Arcan Güven ${ }^{3}$ \\ ${ }^{1}$ Conductive Technologies Inc., New Product Research \& Development, 935 Borom Road, York, PA 17404, USA \\ ${ }^{2}$ Integrated Microsystems for the Quality of Life S.L., C/del Ferro 6, Nave 7, 43006 Tarragona, Spain \\ ${ }^{3}$ Department of Cellular and Molecular Physiology, Pennsylvania State University College of Medicine, 500 University Drive, Hershey, \\ PA 17033, USA \\ Correspondence should be addressed to Güray Güven; gguven@conductivetech.com
}

Received 18 September 2013; Revised 4 November 2013; Accepted 5 November 2013

Academic Editor: Miloslav Pravda

Copyright (C) 2013 Güray Güven et al. This is an open access article distributed under the Creative Commons Attribution License, which permits unrestricted use, distribution, and reproduction in any medium, provided the original work is properly cited.

\begin{abstract}
Alternative to batteries power sources is needed for the human implants of the future that tend to be less invasive and more integrated to human biology and physiology. Human metabolism could be exploited for the generation of power, but mammalian cells protect their energy production apparatus from external electrochemical scavengers. We report here evidence that, in the case of white blood cells, chemical energy can be harvested directly on an electrode as electricity in fuel cells whose stability is roughly parallel to the viability of cells in vitro. Electrochemical activity of human leukocytes immobilized on modified carbon mesh electrodes was investigated by cyclic voltammetry. Oxidation peaks at $0.33 \mathrm{~V}$ versus $\mathrm{Ag} / \mathrm{AgCl}$ were observed. An open-circuit potential of $0.44 \mathrm{~V}$ was recorded between anode and cathode compartments where the biofuel cell potential operating under an external load of $5 \mathrm{k} \Omega$ was below $0.35 \mathrm{~V}$. Average power outputs of $10 \mu \mathrm{W}\left(2.4 \times 10^{-6} \mu \mathrm{W} /\right.$ cell $)$ were increased to $15 \mu \mathrm{W}$ by the activation of white blood cells. Power densities of $1.5 \mu \mathrm{W} \mathrm{cm}{ }^{-2}$ for lower than physiological cell concentrations are low for most of today's implants, but possibility of cell immobilization allows a positive outlook for the future utility of the reported findings.
\end{abstract}

\section{Introduction}

Advances in the medical sciences are leading to an increasing number and type of implantable electrically operated devices. One of the problems with these medical devices is their power supply requirements. Batteries are mostly used for this purpose. However, batteries have a limited lifetime and they need to be replaced. Implanted medical devices need power supplies that will operate for long periods of time and whose maintenance would not necessitate surgery. Ideally, implanted devices would take advantage of the natural fuel substances found in the body, and thus they would continue drawing power for as long as the subject lives. If power production is to be integrated in the futuristic implant, one has to look for the sources of power generation and especially the ones that can be used inside the human body in an integrated way. Potentially, there is a way around the limitations of batteries and the very restricted amount of energy available to siphon off: scavenge power from the human body [1].

Power might be scavenged indirectly from the body's everyday actions or might be intentionally generated by the body. Indeed, products (flashlights, radios, watches, etc.) have been on the market for years operating in this mode and researchers are driven to produce other devices into this niche, while finding alternative ways to draw excess energy from human activity $[2,3]$. Power recovery from body heat, breathing, blood pressure, typing, arm motion, pedalling, and walking has been considered as power supply methods [4]. Different physiological power sources such as thermal and pressure gradients or different movement-based energy storage devices have been considered as energy suppliers $[4,5]$.

Biofuel cells are an alternative energy source for electrically powered devices. In this study, using the same principle of microbial fuel cells, harvesting of electrochemical 
energy spontaneously generated in a physiological process from mammalian cells to be integrated into a so-called mammalian biofuel cell (MBFC) is proposed. A practical potential application for the MBFC is as power source for implantable medical devices such as glucose sensors, neural stimulators, and "smart" drug delivery chips. MBFC powered device has the need for constant, reliable, long-term power provided by a physiological biofuel. Electrochemical response of leukocytes has been reported previously in voltammetric experiments in simple three-electrode systems using bare graphite as working electrodes $[6,7]$. The response obtained in such setup showed anodic currents obtained at oxidative potentials; however, the origin of that anodic response was not clearly identified and the lifetime of that signal lasted few voltammograms. Preliminary studies have explored the current response of human leukocytes/lymphocytes in fuel cell setups [8-11]. Characterization of the obtained net power output is described in this paper for the first time.

The proposed MBFC power output required the supply of electrons from a mammalian cell-based source to be coupled with an electrode in a nondestructing way for the living organism (Figure 1). At the anode part of the MBFC, intracellular electrons are generated in the cytosolic environment of the cell and subsequently released through extramembrane transport process. It was assumed that NADPH oxidase enzyme, found in the leukocyte family of blood cells, allows the production of extracellular currents (Figure 1(a)) as it does during the body immune response mechanism [12]. However, there may be another source for the current production (Figure 1(b)): electrochemically active molecules may be released from cells to the extracellular surroundings where they can come in contact with the electrode producing currents. An example of this process is the release of serotonin and coenzyme A from leukocyte family cells, which have been reported to produce currents in in vitro studies $[13,14]$. Electrochemical studies of serotonin oxidation-reduction reactions at electrode surfaces have been previously conducted [15]. Release of serotonin (5-hT) from activated white blood cells may be followed by oxidation of the neurotransmitter to 5-hydroxyindoleacetic acid (5-hIAA) in the leukocyte-based biofuel cell setup [16].

As explained, the mechanism of electron transfer is not immediately obvious. The alternatives explained above have been considered for the origin of the currents obtained from MBFC setup, classified here as intracellular and extracellular. In this work, we describe the harvesting of the electrochemical energy generated by a leukocyte cell-based biofuel cell setup. Additional studies are currently undergoing to further identify the molecule(s) involved in the energy production process but what it is undeniable is the proof of principle that human leukocytes can be used as biocatalysts for mammalian biofuel cells.

\section{Materials and Methods}

2.1. Isolation of White Blood Cells from Venous Blood. Human whole blood was extracted from healthy donors at the Hospital Universitari de Tarragona Joan XXIII (Spain).

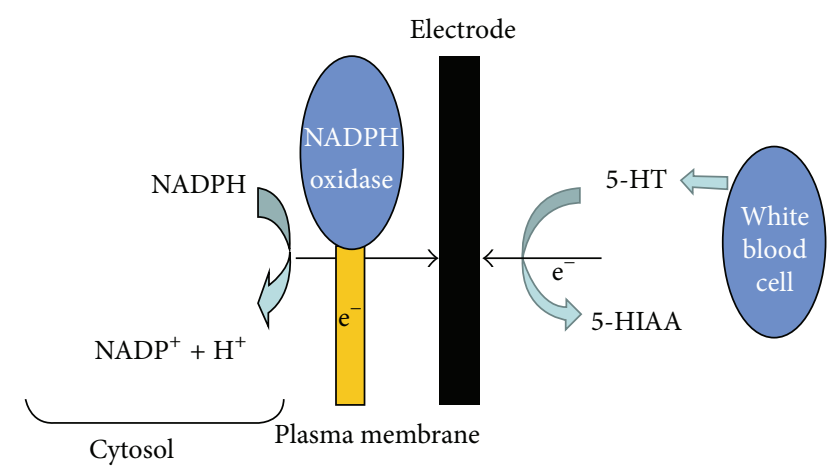

(a)

(b)

FIGURE 1: Direct (a) and indirect (b) electron transfer mechanism of white blood cells.

A blood volume of $30 \mathrm{~mL}$ was collected and placed in $50 \mathrm{~mL}$ sterilized tube (Deltalab). The tube was then filled up to $50 \mathrm{~mL}$ with $0.1 \mathrm{M}$ phosphate buffered saline solution ( $\mathrm{pH}$ $7.4 ; 0.01 \mathrm{~mol} / \mathrm{L} \mathrm{Na}_{2} \mathrm{HPO}_{4} ; 0.001 \mathrm{~mol} / \mathrm{L} \mathrm{KH}_{2} \mathrm{PO}_{4} ; 0.13 \mathrm{~mol} / \mathrm{L}$ $\mathrm{NaCl} ; 0.002 \mathrm{~mol} / \mathrm{L} \mathrm{KCl}$; Sigma Aldrich). $15 \mathrm{~mL}$ of Ficollsodium metrizoate solution (LSM 1077, PAA) was placed into each of two $50 \mathrm{~mL}$ tubes. The blood-phosphate buffer suspension was then transferred into each of the two tubes in equal volumes. Centrifugation with MPW Centrifuge (Med Instruments; Poland) at $2000 \mathrm{rpm}$ for 25 minutes was then performed. After centrifugation, aspirated leukocytes were placed into two separate $50 \mathrm{~mL}$ tubes. The tubes were subsequently filled to $50 \mathrm{~mL}$ with phosphate buffered saline. The cells were centrifuged at $1700 \mathrm{rpm}$ for 15 minutes and the supernatant was removed. Before use in all experiments, cells were kept in cell culture medium containing RPMI 1640 media (PAA) supplemented with $10 \%$ fetal bovine serum (FBS, PAA) and $1 \% 100$ units $\mathrm{mL}^{-1}$ penicillin- $100 \mu \mathrm{g} \mathrm{mL}^{-1}$ streptomycin (PAA) solutions. Cells were incubated at $37^{\circ} \mathrm{C}$ and $5 \% \mathrm{CO}_{2}$ in an incubator (Galaxy, R.S. Biotech; UK).

For the biofuel cell experiments, $10 \mathrm{~mL}$ of cell suspension was put into a $50 \mathrm{~mL}$ tube. The volume was brought up to $50 \mathrm{~mL}$ with sterile PBS. The solution was agitated to make it homogenous and then the tube was centrifuged like the washing step of isolation as explained above. After the centrifugation step, the upper layer was removed and cells were transferred to the anode. The effect of in vitro leukocyte activation was investigated by injection of phorbol ester. Ten $\mu \mathrm{L}$ of PMA ( $5 \mathrm{ng} \mathrm{cm}^{-3}$, Fluka) was added to cell culture medium and the cells were incubated for 5 hours in the incubator $\left(37^{\circ} \mathrm{C}\right.$ and $\left.5 \% \mathrm{CO}_{2}\right)$. After 5 hours, routine procedure for immobilization on the modified electrode and electrochemical measurements were followed for activated cells.

2.2. Electrochemical Experiments. Electrochemical measurements were obtained using cyclic voltammetry with a $\mathrm{CHI}$ Electrochemical Analyzer ( $\mathrm{CH}$ Instruments, Austin, TX, USA) interfaced with a PC. Cyclic voltammograms (CV) 


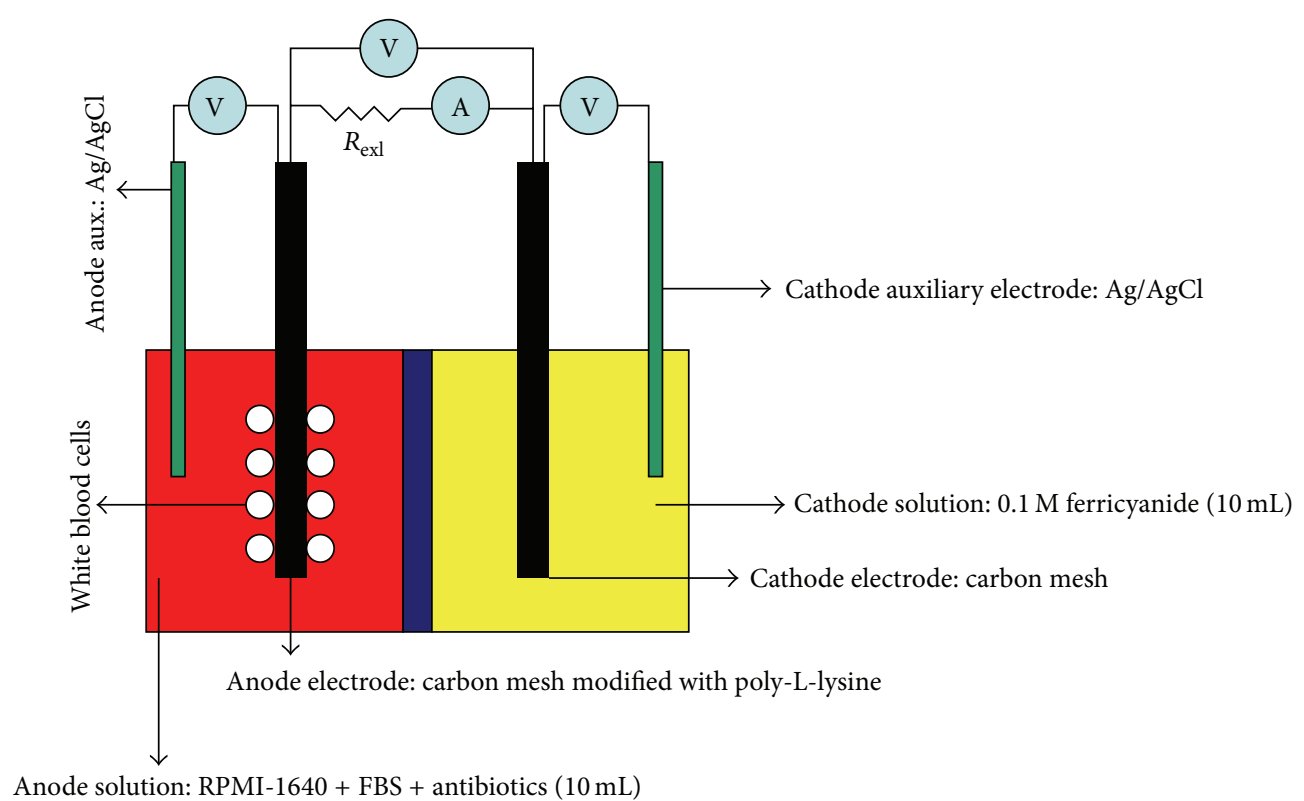

FIgURE 2: Schematic view of mammalian biofuel cell.

were taken repeatedly at a scan rate of $10 \mathrm{mV} / \mathrm{s}$. Electrochemistry studies were performed with two-cell configurations. The first one was a three-electrode system of a UniJet radial thin layer cell (Bioanalytical Systems, USA) with a groove of small volume of about $20 \mu \mathrm{L}$. The working electrode is a $3 \mathrm{~mm}$ glassy carbon electrode. Stainless steel was the counter electrode whereas the reference electrode was prepared with formation of the $\mathrm{AgCl}$ film accomplished by applying a small drop of coating solution (Bioanalytical Systems, USA) to the Ag electrode for 1 minute. The potential of such an $\mathrm{AgCl}$ coated Ag reference electrode was found to be stable $(-0.043 \mathrm{mV}$ versus SCE). The buffer used, unless otherwise noted, was the culture medium of the cells. MilliQ water was used throughout all the experiments. Before the electrochemical experiments, glassy carbon electrodes were polished with 0.3 micron alumina (Buehler, USA).

Leukocytes were layer-by-layer immobilized over glassy carbon electrode surfaces that were modified with polyL-lysine (PLL; 0.1\% w/v in water; Sigma Aldrich). PLL is a biodegradable cationic polyelectrolyte. Positively charged amino groups of PLL interact with the negatively charged cell surface and undergo a bioadhesion [17]. For the immobilization, $25 \mu \mathrm{L}$ of PLL was dropped on the electrode and incubated at room temperature for 1 hour. Next, the cells were transferred onto the electrode modified with PLL and allowed to immobilize for 15 minutes. Prior to electrochemical experiments, electrodes were rinsed with distilled water in order to remove nonattached cells.

For the characterization of anode and cathode electrodes of the mammalian biofuel cell, a typical three-electrode system with standard $\mathrm{Ag} / \mathrm{AgCl}$, sat. $\mathrm{KCl}$, reference electrode, and a platinum counter electrode was used. Carbon mesh electrodes which are modified with PLL for the anode characterization and nonmodified carbon mesh electrodes for the cathode characterization were used as working electrodes as used in the MBFC setup. Buffer solutions were cell culture medium, RPMI-1640 supplemented with 10\% FBS and antibiotic solution, and $0.1 \mathrm{M}$ potassium ferricyanide for anode and cathode, respectively.

2.3. Biofuel Cell Measurements. The materials for the construction of the MBFC, including Perspex pieces, neoprene gaskets, screws, bolts, carbon felt electrodes $\left(\sim 10 \mathrm{~cm}^{2}\right.$ as anode and cathode electrodes), and proton exchange membrane (PEM) were obtained from the National Center for Biotechnology Education at the University of Reading (Reading, UK). The MBFC consists of two separate compartments, which are an anode and a cathode chambers, separated by a membrane (Figure 2). The lymphocyte or leukocyte suspension in $10 \mathrm{~mL}$ of cell culture medium was placed in the anode compartment. Carbon felt electrodes used in the anode chamber are pretreated with PLL. For this reason carbon mesh electrodes are immersed in PLL solution for 15 minutes and then dried for 1 hour. The cathode solution is made of $0.1 \mathrm{M}$ potassium ferricyanide. Before MBFC experiments, all parts of the assembly are sterilized with UV light for 20 minutes. Next, the cells are transferred onto the anode electrode and the electrode is left for 15 minutes in contact with them for the adhesion of cells. After 15 minutes, the electrodes are rinsed with distilled water in order to remove the nonattached cells. Currently, cell voltage, auxiliary voltages, and power output were measured by a battery-cell tester (Model 4300, Maccor, USA). For the determination of the power output, a variable resistance was used as an external load. External resistances were applied by the battery-cell tester. $\mathrm{Ag} / \mathrm{AgCl}$ electrodes are used as auxiliary electrodes.

2.4. Viability Measurements. Viability measurements were performed by counting the cells before and after setting up 
electrochemical experiments by $0.4 \%$ trypan blue solution (Sigma-Aldrich) with a haemocytometer (Brand $\mathrm{GmbH}$, Germany).

\section{Results and Discussion}

3.1. Electrochemical Characterization and Voltammetric Behavior of Leukocytes. Cyclic voltammetry (CV) was used to validate whether the white blood cells are capable of electron transfer to the electrodes. Peaks in the voltage-current curves would be observed at potentials corresponding to the potentials of any electrochemically active species present, whether bound to the cell membrane or dissolved in solution. Oxidation peaks were always observed in the presence of leukocytes but never in their absence. Figure 3(a) shows the CV of leukocytes on glassy carbon electrode. Peaks at around $0.33 \mathrm{~V}$ versus $\mathrm{Ag} / \mathrm{AgCl}$ were observed whereas there was no response in the absence of the cells. This result can be interpreted as leukocytes have an electrochemical activity. The peak currents at $0.33 \mathrm{~V}$ versus $\mathrm{Ag} / \mathrm{AgCl}$ for $2 \times 10^{6}$ and $1 \times 10^{6}$ leukocyte cells were 1.92 and $0.58 \mu \mathrm{A}$, respectively (Figure $3(\mathrm{~b})$ ). A positive correlation between cell number and peak current across the leukocyte samples observed shows the role of the leukocytes as a significant source of electrons. The relation between cell number and peak current appears to be nonlinear. However, this may be an apparent nonlinearity as variability in how strong cells from subjects respond to the electrochemical reaction can occur. As a consequence, this would affect how much serotonin is produced.

Upon scan reversal, no corresponding reduction peak was obtained (Figure 3(a)). This shows that the electrochemical reaction observed as a result of the presence of leukocytes was irreversible. After several scans, the peak current dropped dramatically; however, only the first scans were shown in Figure 3(a). This decrease in the peak current at the following scans may be due to the poisoning of the electrode surface or the decrease in cell activity [7]. In addition, the background current observed for the blank glassy carbon electrode and electrode coated with PLL did not show a significant difference. This result shows that PLL does not affect the significantly electrochemical behavior.

The effect of cell activation is shown in Figure 4. Addition of activator (PMA) did not cause a change at the peak potential which is again observed at around $0.33 \mathrm{~V}$. Nevertheless, the peak current of $2 \times 10^{6}$ cells appeared to increase from 1.92 to $3.62 \mu \mathrm{A}$, suggesting an increased activity of the cells due to the activator. It is clear that the leukocytes are indeed capable of electron transfer. However, the peak current at $0.33 \mathrm{~V}$ versus $\mathrm{Ag} / \mathrm{AgCl}$ obtained from leukocytes seems to be related to other compounds. White blood cells have cytoplasmic granules containing mediators of anaphylaxis such as histamine, serotonin, eosinophil chemotactic factor, and neutrophil chemotactic factor.

Previous works have reported that the peak potential of serotonin appeared at $0.29-0.34 \mathrm{~V}$ versus SCE at pyrolytic graphite electrodes [18] and carbon fiber microelectrodes [19]. The redox species responsible for the oxidation peak,

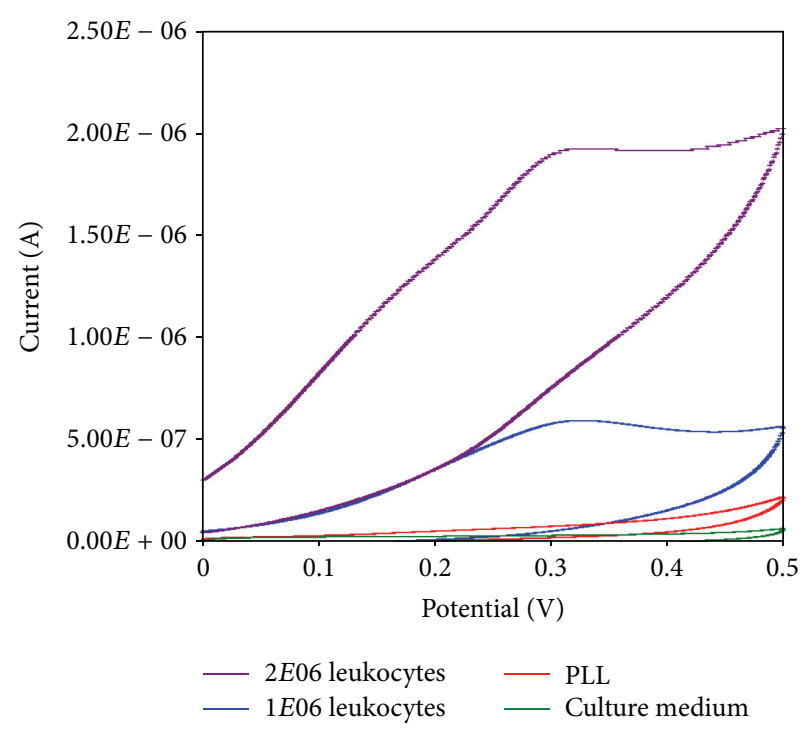

(a)

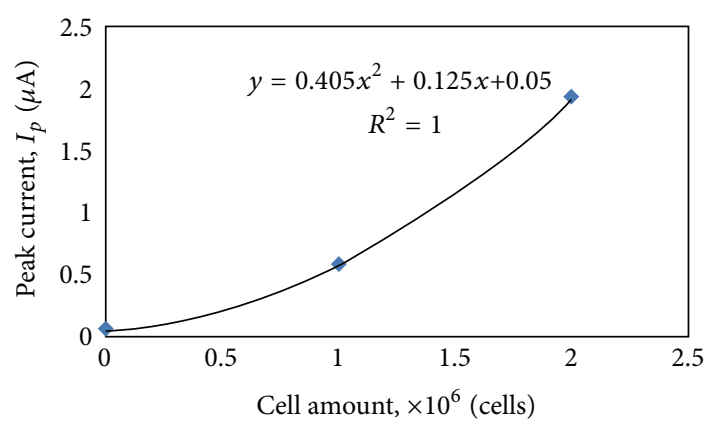

(b)

FIGURE 3: (a)CV of leukocytes attached on glassy carbon electrode modified with poly-L-lysine. Purple: $2 \times 10^{6}$ leukocyte response; blue: $1 \times 10^{6}$ leukocyte response; red: modified glassy carbon electrode buffer response; green: glassy carbon electrode culture medium response; potential range: $-0.5-0.5 \mathrm{~V}$; scan rate: $10 \mathrm{mV} / \mathrm{s}$; buffer solution: culture medium (RPMI-1640 + FBS + antibiotic solution); working electrode: $3 \mathrm{~mm}$ glassy carbon electrode; counter electrode: stainless steel; and reference electrode: $\mathrm{Ag} / \mathrm{AgCl}$ (-0.043 $\mathrm{mV}$ versus SCE). (b) Calibration curve for increasing leukocyte amount.

during the cyclic voltammogram of leukocyte (Table 1), can be serotonin $(5-\mathrm{HT})[13-15,20]$, with an exemption of a study referring membrane-bound proteins for the source of the oxidation peak [6]. It has been suggested that $5-\mathrm{HT}$ is released from certain human leukocytes during inflammatory responses, particularly in response to allergens during allergic reaction [9]. The oxidation peak for 5-HT was detected at $0.29-0.34 \mathrm{~V}$ versus SCE (Table 1 ), which is a slightly lower value than what has been detected in our study ( $0.37 \mathrm{~V}$ versus SCE). The difference may not be significant since scan conditions and electrode surface features can significantly impact the peak potential. An oxidation peak of human leukocytes at $0.36 \mathrm{mV}$ versus SCE has been previously reported when carbon felt electrodes were used in a study where the release of serotonin from the PMA activated cells 
TABLE 1: Cyclic voltammetry studies of leukocytes (derived from [11]).

\begin{tabular}{|c|c|c|c|c|}
\hline Cells & Working Electrode & $\begin{array}{c}\text { Leukocyte peak potential, } \\
E_{p}(\mathrm{~V} \text { versus SCE) }\end{array}$ & $\begin{array}{c}\text { Electroactive species/potential } \\
\text { (V versus SCE) }\end{array}$ & Reference \\
\hline Human leukocytes & $\begin{array}{c}\text { Basal plane } \\
\text { Pyrolytic graphite }\end{array}$ & 0.33 and 0.68 & $\begin{array}{l}\text { Serotonin } / 0.29-0.34 \\
\text { CoA } / 0.65-0.74\end{array}$ & {$[14]$} \\
\hline $\begin{array}{l}\text { Rat basophilic leukemia } \\
\text { cells (RBL-1) }\end{array}$ & $\begin{array}{l}\text { Basal plane } \\
\text { Pyrolytic graphite }\end{array}$ & 0.34 and 0.68 & $\begin{array}{l}\text { Serotonin } / 0.29-0.34 \\
\quad \text { CoA } / 0.65-0.74\end{array}$ & [13] \\
\hline White rabbit leukocytes & Graphite & 0.32 & $\begin{array}{l}\text { Membrane-bound } \\
\text { proteins/n/a }\end{array}$ & {$[6]$} \\
\hline
\end{tabular}

was confirmed by HPLC analysis [11]. The absence of a reduction peak was often reported in these studies and has been attributed to the irreversible oxidation of serotonin (5HT) to 5-hydroxyindoleacetic acid (5-HIAA) [15]. However, no clear correlation of the CV shape with the electron transfer mechanism can be established yet. Only the confirmation of the correlation between the cell number, activation, and electron transfer is established.

3.2. Characterization of Anode and Cathode Electrodes of Mammalian Biofuel Cell. Like other biofuel cell types, for MBFC calculations, it is more convenient to evaluate the reaction in terms of the overall cell electromotive force (emf) $E_{\text {emf }}(\mathrm{V})$, defined as the potential difference between the cathode and anode. $E_{\text {emf }}$ has to be positive for a favourable reaction. The theoretical emf provides an upper limit for the cell voltage; the actual potential derived from the MBFC will be lower due to various potential losses. The cell emf is calculated as

$$
E_{\text {cell }}=E_{\text {cathode }}-E_{\text {anode }} \text {, }
$$

where the minus sign is a result of the definition of the electron flow towards cathode and away from anode. As the cell emf has to be positive from its definition, the anode potential $E_{\text {anode }}(\mathrm{V})$ should be lower (more negative) than the cathode potential, $E_{\text {cathode }}(\mathrm{V})$. The higher the difference between the anode and cathode redox potentials, the higher the possible energy gained from the MBFC. In order to investigate the response of the anode and cathode, CVs of the MBFC electrodes were studied, separately. The voltammetric response of the leukocytes was characterized by carbon felt electrodes modified with PLL. From the voltammogram which is shown in Figure 5 the anode starts producing an oxidative current at a potential of $-0.03 \mathrm{~V}$ versus $\mathrm{Ag} / \mathrm{AgCl}$ measured at scan rate of $10 \mathrm{mV} / \mathrm{s}$.

The cathodic peak of ferricyanide, which is shown in Figure 6, reaches its plateau at approximately $0.41 \mathrm{~V}$ versus $\mathrm{Ag} / \mathrm{AgCl}$. However, the reduction current appears between $0.50 \mathrm{~V}$ and $0.28 \mathrm{~V}$. Therefore, there is a window tray from $-0.03 \mathrm{~V}$ to $0.28 \mathrm{~V}$ where the spontaneous operation of the biofuel cell is thermodynamically possible.

In order to evaluate the influence of integration, biofuel cell potential should be measured. The cell emf is a thermodynamic value that does not take into account internal potential losses. The open circuit potential (OCP) is the cell voltage that can be measured after some time in the absence of current. Theoretically, the OCP should approach the cell

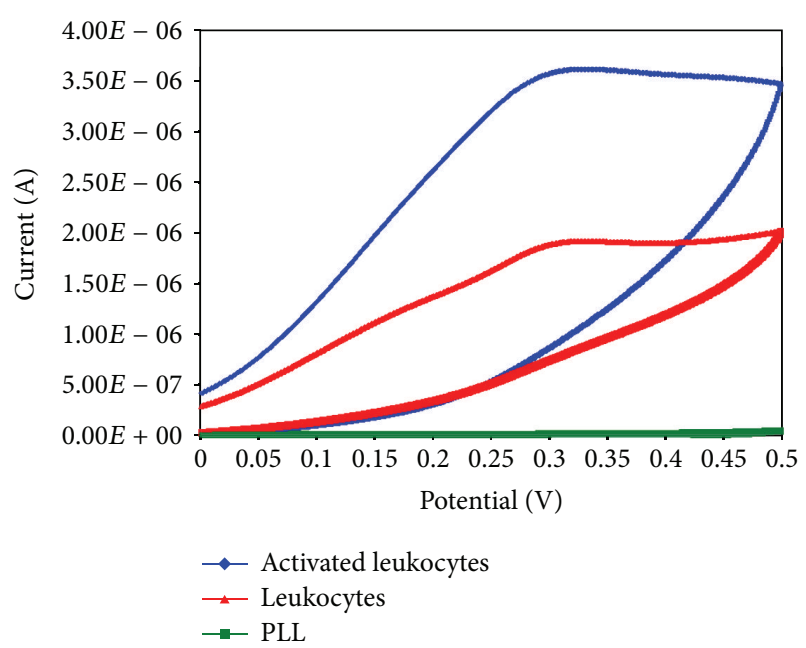

FIGURE 4: CV results of cell activation. Blue: $2 \times 10^{6}$ activated leukocytes response immobilized on glassy carbon electrode modified with PLL; red: $2 \times 10^{6}$ leukocyte response immobilized on glassy carbon electrode modified with PLL; green: glassy carbon electrode modified with PLL culture medium response; potential range: $-0.5-$ $0.5 \mathrm{~V}$; scan rate: $10 \mathrm{mV} / \mathrm{s}$; buffer solution: culture medium (RPMI1640 + FBS + antibiotic solution); working electrode: $3 \mathrm{~mm}$ glassy carbon electrode; counter electrode: stainless steel; and reference electrode: $\mathrm{Ag} / \mathrm{AgCl}(-0.043 \mathrm{mV}$ versus SCE).

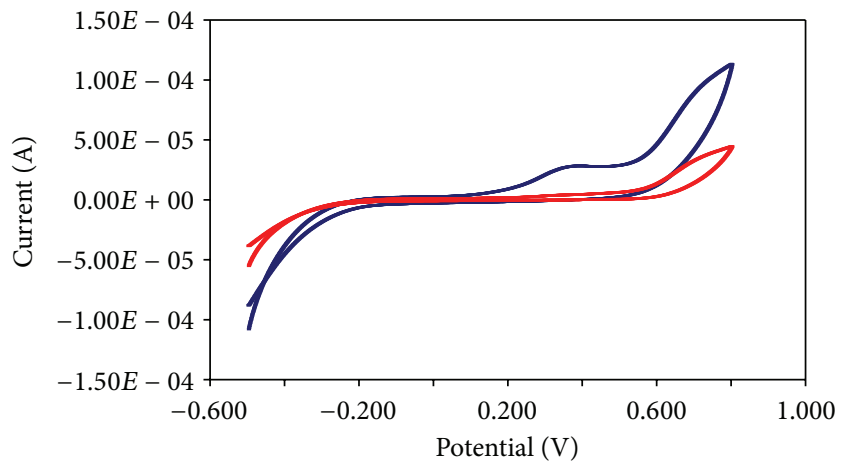

FIGURE 5: CV of anode electrode-oxidation of leukocytes. Blue: response of leukocytes; red: response of carbon felt electrode modified with PLL, potential range: $-0.5-0.8 \mathrm{~V}$; scan rate: $10 \mathrm{mV} / \mathrm{s}$; buffer: culture medium; working electrode: carbon felt; counter electrode: platinum; and reference electrode: $\mathrm{Ag} / \mathrm{AgCl}$, sat. $\mathrm{KCl}$. 


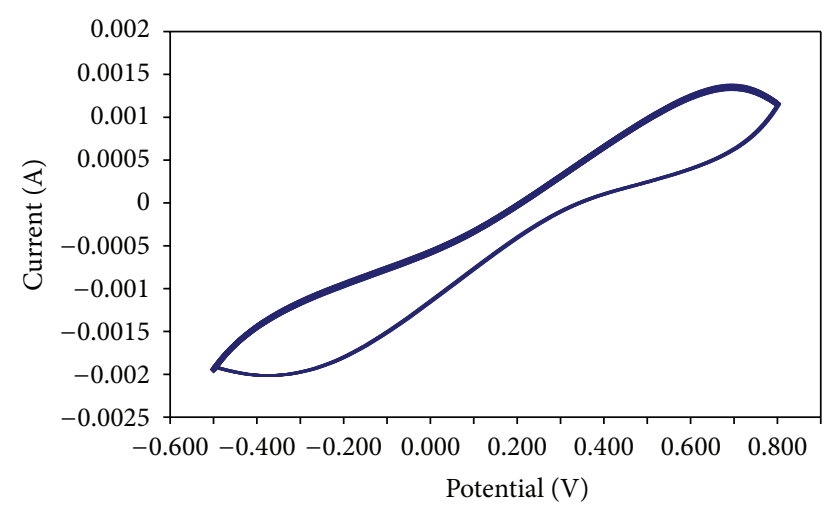

FIGURE 6: CV of cathode electrode-reduction of ferricyanide (buffer: $0.1 \mathrm{M}$ potassium ferricyanide; potential range: $-0.5-0.8 \mathrm{~V}$; scan rate: $10 \mathrm{mV} / \mathrm{s}$; working electrode: carbon felt; counter electrode: platinum; and reference electrode: $\mathrm{Ag} / \mathrm{AgCl}$, sat. $\mathrm{KCl}$ ).

emf. In practice, however, the OCP is substantially lower than the cell emf, due to various potential losses. As it is shown in Figure 7(a), in an open circuit, when no current is flowing, the maximum MBFC voltage achieved is $0.44 \mathrm{~V}$. However, Figure 7(b) shows that when a load is applied, the voltage remains below $0.35 \mathrm{~V}$. In all cases, the anode potential was lower than the cathode potential which shows again that the electrochemical reactions that drive the MBFC are thermodynamically favourable. OCP for each electrode also corresponds to the (in theory) equilibrium potential of the reaction occurring. It is observed that the potential values where the reaction started in the CVs of Figures 5 and 6 were very similar to the OCPs in the MBFC setup. However, anode OCP almost coincides with the zero current potential of Figure 5. It is obvious from Figure 7(b) that the behaviour of the anode limits the overall performance of the mammalian biofuel cell.

3.3. Power Production from MBFC. The overall performance of a MBFC is evaluated by its power output. Power is calculated as

$$
P=i \cdot E_{\text {cell }} \text {. }
$$

To evaluate the power generation, a decreasing resistance from $60 \mathrm{k} \Omega$ to $100 \Omega$ at a time interval of 10 seconds in each load was applied and the current and cell potentials for each resistance were measured. Later, the applied resistor, cell potential, and current were used to calculate power. Therefore, it can be said that power generated by MBFC was computed as a product of current passing through an external load and voltage drop across the resistor.

An example of measurement showing how current and cell potential change with the external resistance is shown in Figure 8. If the applied load is very low, then high instantaneous current transfer occurs causing a high power generation. At the same time, increase in the electron transport between two compartments means a decrease in the potential difference between anode and cathode. However, under that circumstance when the MBFC is not sustainable, the cell

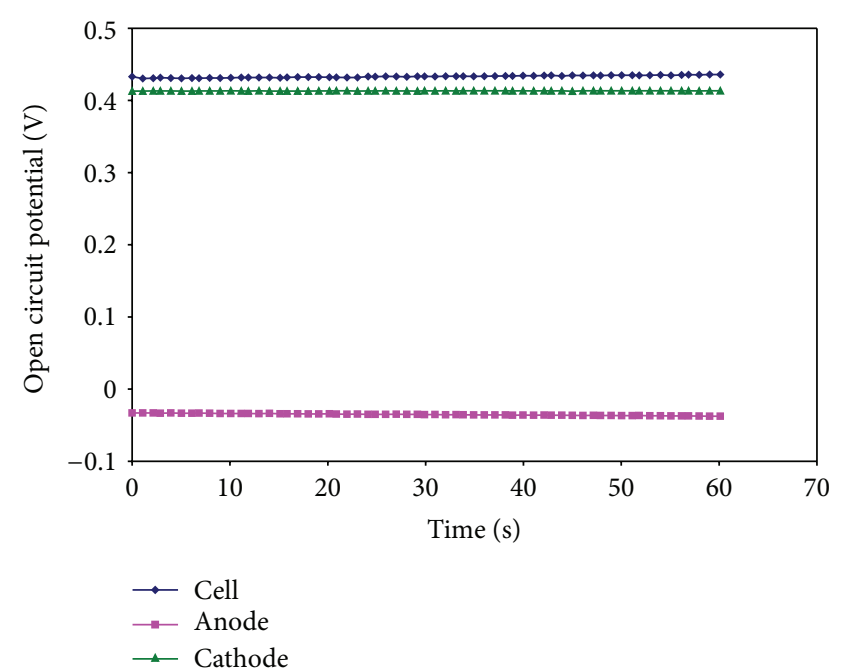

(a)

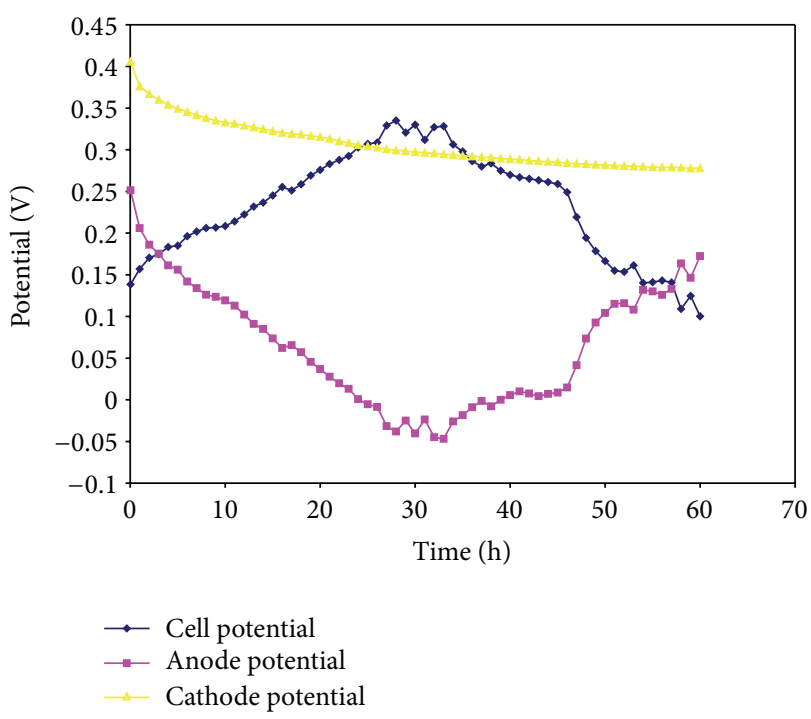

(b)

FIGURE 7: (a) Open circuit potentials of cell, anode, and cathode. (b) Anode, cathode, and cell potentials of MBFC operating under an external load of $5000 \mathrm{ohm}$.

cannot deliver that much power for long periods of time as the cell potential drops quickly. From the data in Figure 8, potentials (obtained with $\mathrm{Ag} / \mathrm{AgCl}$ auxiliary electrodes) of the cathode, anode, and cell against the external load are plotted in Figure 9. The cathodic potential was constant at each external load, showing that the power is limited by the anode [21].

When the external load is low, the anode potential became more positive and increasingly close to the cathode potential with decreasing external load due to the low external resistance. The anode reaction is forced to accelerate, therefore shifting to more positive potentials. Assumably, when a low external load is applied, the electron delivery to the cathode is limited by the anode electrode kinetics, though mass transfer may be limiting. In any case, at these loads, internal 


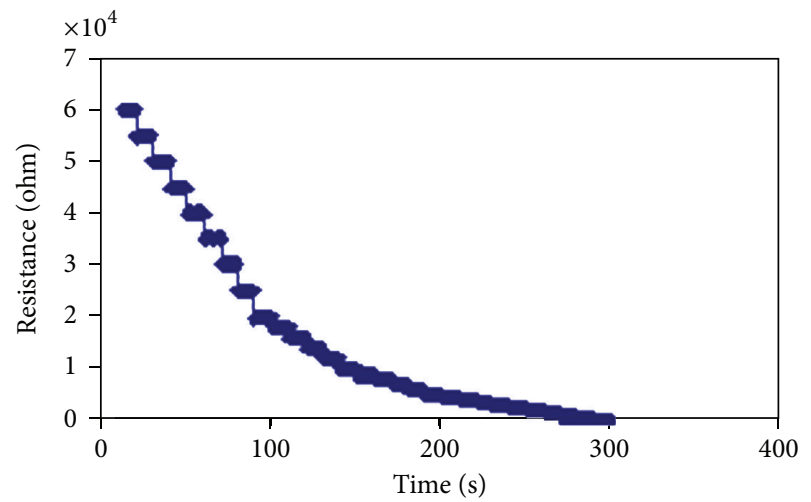

(a)

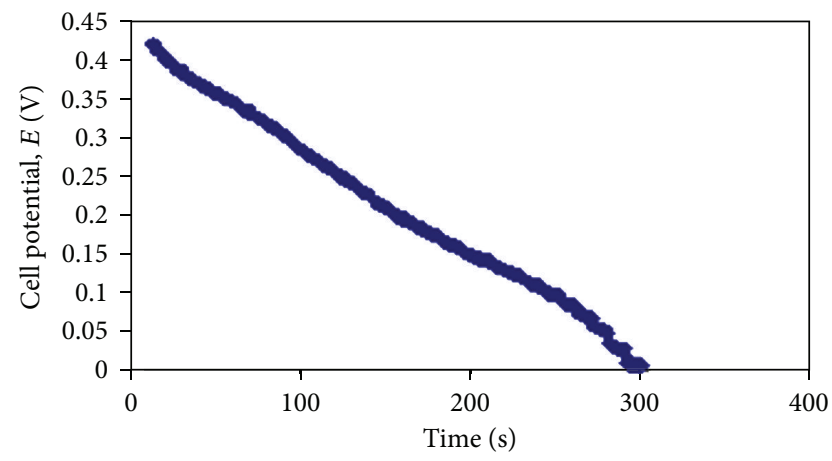

(b)

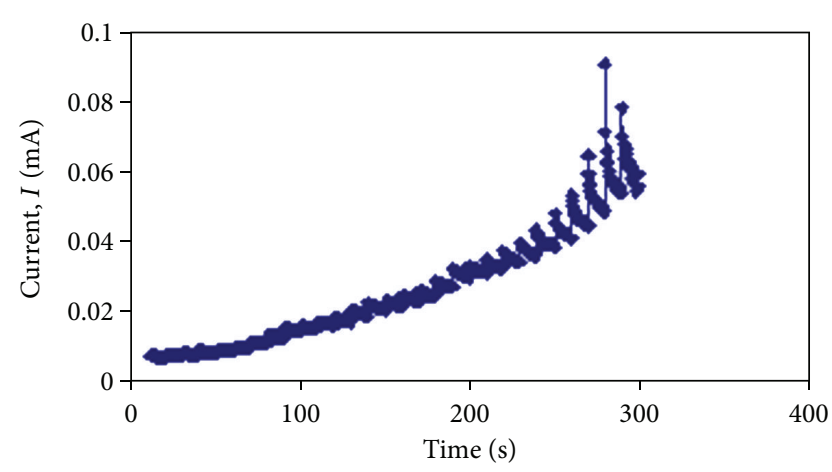

(c)

FIGURE 8: Effect of applied external resistance on the variations of cell potential ( $E$, potential difference between anode and cathode) and current $(I)$. Anode solution: $10 \mathrm{~mL}$ of cell culture medium; anode electrode: carbon felt modified with PLL $\left(\sim 10 \mathrm{~cm}^{2}\right)$; cell density: $1 \times 10^{6}$ cells $/ \mathrm{mL}$; cathode solution: $0.1 \mathrm{M}$ potassium ferricyanide; and cathode electrode: carbon felt $\left(\sim 10 \mathrm{~cm}^{2}\right)$.

resistance phenomena is limiting the power. In the other extreme (high load), external resistance limitations make the dependence of potential almost linear with external load. The conditions where external and internal resistance limitations are equal must be somewhere between these two lines, which is presented in the rectangular area $(\mathrm{A}=\mathrm{B})$ in Figure 9 [22]. This shows that power generation from MBFC reached its maximum values where external resistance was equal to internal resistance, something that should occur between 3 and $18 \mathrm{k} \Omega$ of load.

3.4. White Blood Cell Dependency on the Power Outcome of $M B F C$. Human leukocytes/lymphocytes were isolated from venous blood under sterile conditions using a Ficoll-Paque density gradient medium. Two lymphocyte fractions containing $4.4 \times 10^{6}$ and $4.2 \times 10^{6}$ cells $/ \mathrm{mL}$ obtained from two different healthy donors were tested under the same conditions. Additionally a fraction $\left(2.7 \times 10^{6}\right.$ cells $\left./ \mathrm{mL}\right)$ containing the rest of leukocyte family was also analyzed. After the isolation, the different cells were resuspended in $10 \mathrm{~mL}$ of $0.1 \mathrm{M} \mathrm{pH}$ 7.4 PBS and placed in the anode compartment of the MBFC at a maintained temperature of $37^{\circ} \mathrm{C}$. The cathode solution was made of $0.1 \mathrm{M}$ potassium ferricyanide to establish an Fe (III) to $\mathrm{Fe}$ (II) reduction reaction.

Figure 10 shows the power outputs obtained at variable external resistance loads between $50 \mathrm{k} \Omega$ and $100 \Omega$. It was observed how upon an increase of the load resistance the recorded powers from the two lymphocyte fractions increased up to a maximum net value of ca. $10 \mu \mathrm{W}(2.4 \times$ $10^{-6} \mu \mathrm{W} /$ cell) at an external load between 3.5 and $5.0 \mathrm{k} \Omega$ followed by a gradual decay as the external load is increased, indicative of typical fuel cell behaviour. This behaviour of MBFC exactly matches with thermodynamics which dictates that maximum power output is reached when the external load is equal to the internal resistance [23], which depends upon all internal processes susceptible to generate a resistance against mass or charge flow created during the operation of the fuel cell. It was noticed that there was no significant difference in the maximum power outputs from donor samples 1 and 2; only a slight difference in the external load applied to reach that maximum was observed.

Similar behaviour was observed from the fraction containing the rest of leukocyte family cells (neutrophils, monocytes, eosinophils, and basophils); a maximum power was observed under similar resistance load followed by a gradual decay. However, the net power obtained ca. $4.05 \mu \mathrm{W}(1.5 \times$ $10^{-6} \mu \mathrm{W} /$ cell) was lower than that obtained from the lymphocyte fraction, suggesting a steadier electrochemical response.

Following the response of cells right after isolation, the effect of in-vitro lymphocyte cell activation and incubation was investigated. Lymphocytes can be activated by phorbol esters such as phorbol 12-myristate 13-acetate (PMA). PMA affects cytosolic protein kinase $\mathrm{C}(\mathrm{PKC})$ by mimicking a natural ligand and activator of $\mathrm{PKC}$, which induces the assembly and activation of NADPH oxidase at the membrane [24-29].

Lymphocytes were cultured in a growth medium. $10 \mu \mathrm{L}$ of PMA ( $5 \mathrm{ng} \mathrm{cm}^{-3}$ ) was added to the culture medium. Lymphocytes were incubated at $37^{\circ} \mathrm{C}$ and $5 \% \mathrm{CO}_{2}$ atmosphere for 5 hours. When the lymphocytes were introduced in the anode compartment after incubation, the power increase observed reached approximately a $20 \%$; however, it was when the lymphocytes were activated and incubated directly in contact with the carbon mesh electrodes when cells showed a better power response. Figure 11 shows how maximum power output increased by approximately $50 \%$, which highlights 


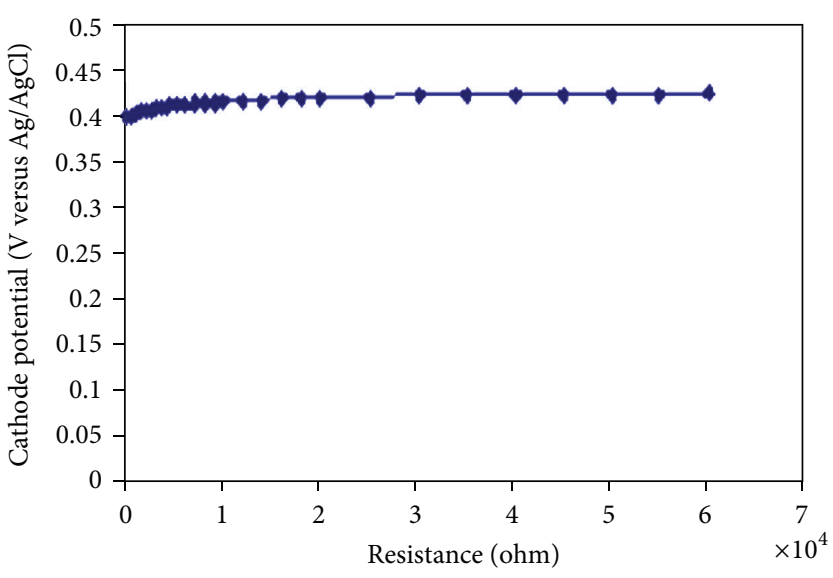

(a)

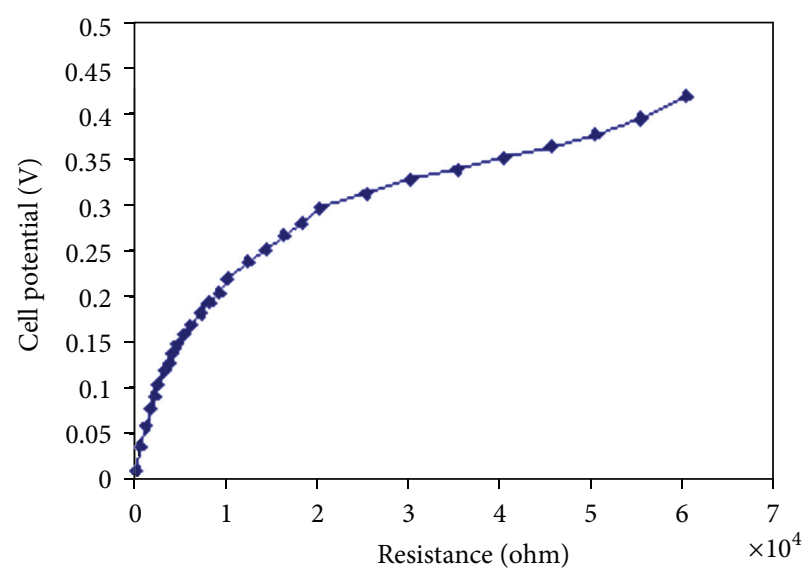

(b)

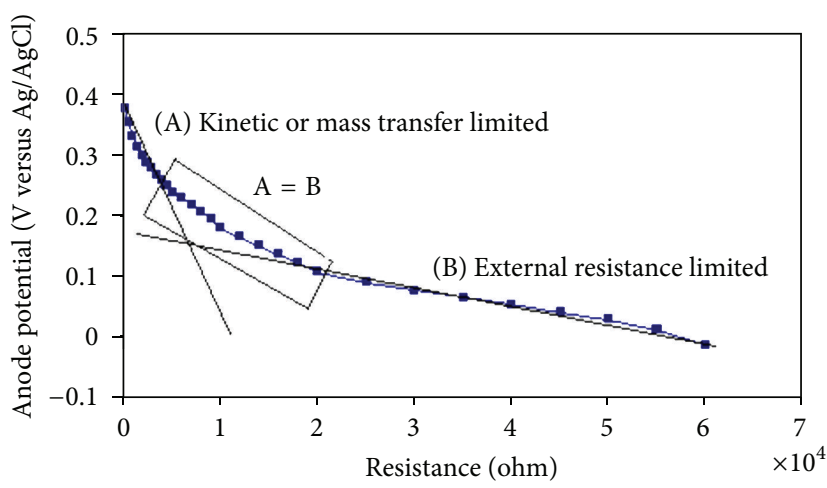

(c)

FIGURE 9: Effect of external resistance on the cathodic, anodic, and cell potentials. Anodic and cathodic potentials are presented against a saturated $\mathrm{Ag} / \mathrm{AgCl}$ electrode. The linear fit at high external resistances (region B) represents a region in which the external resistance controls the power. The linear fit at low external resistances (region A) represents a region in which the power is limited by kinetics, mass transfer, or internal resistance. Anode solution: $10 \mathrm{~mL}$ of cell culture medium; anode electrode: carbon felt modified with PLL $\left(\sim 10 \mathrm{~cm}^{2}\right)$; cell density: $1 \times 10^{6}$ cells/mL; cathode solution: $0.1 \mathrm{M}$ potassium ferricyanide; cathode electrode: Carbon felt $\left(\sim 10 \mathrm{~cm}^{2}\right)$; and reference electrodes: $\mathrm{Ag} / \mathrm{AgCl}$, sat. $\mathrm{KCl}$.

the significance of the activation to increase the generation of currents and power outputs.

Although it is comparable or higher than the various implanted enzymatic biofuel cells (Table 2), it should be noted that the presently achieved ca. $10-15 \mu \mathrm{W}$ power generated by MBFC using human white blood cells, used as model for the human physiology, is below the limit required for activating implantable medical devices. As instance, a pacemaker, powered by an enzymatic biofuel cell, required $300 \mu \mathrm{W}$ for its operation; thus much bigger electrodes were utilized to generate higher current [30]. However, other kinds of pacemakers can operate at power consumption of ca. $20 \mu \mathrm{W}$ [31], which is still 2-fold higher than that achieved in MBFC operated with nonactivated leukocytes/lymphocytes.

Additionally, the mismatch between the low voltage produced by the $\mathrm{MBFC}(0.43 \mathrm{mV}$, Figure 8$)$ and $\sim 3 \mathrm{~V}$ required by the pacemaker must be compensated by an interfacing circuitry (charge pump and DC-DC converter) which will increase the power demand because of partial dissipation of energy upon the voltage conversion [30]. The real total power delivered by the MBFC $(10-15 \mu \mathrm{W}$ for the electrode area of $10 \mathrm{~cm}^{2}$ ) is certainly not enough for activating implanted biomedical devices. Therefore, the presently achieved parameters in the MBFC need to be significantly improved, particularly by increasing the generated current. The approach in the present study, which is based on the white blood cells immobilized on the electrodes, might be a model for the biofuel cells based on the electrodes implanted inside blood vessels.

Without further optimization of the system, the stability of the power output was examined. Lymphocytes were activated with PMA and incubated over the electrode for 5 hours as described previously. Cells were suspended in culture medium and placed in the anode compartment; however, there was no medium replacement during the entire experiment. As seen in Figure 12, the long-term power output experiment showed a drastic decrease in the power measured after $16 \mathrm{~h}$, after which in less than $3 \mathrm{~h}$ that power was almost zero. A sample of anode solution was taken after those $16 \mathrm{~h}$ to analyse the presence and viability of the cells. It was observed that a vast amount of dead cells were resuspended in the solution instead of being attached to the electrode. 


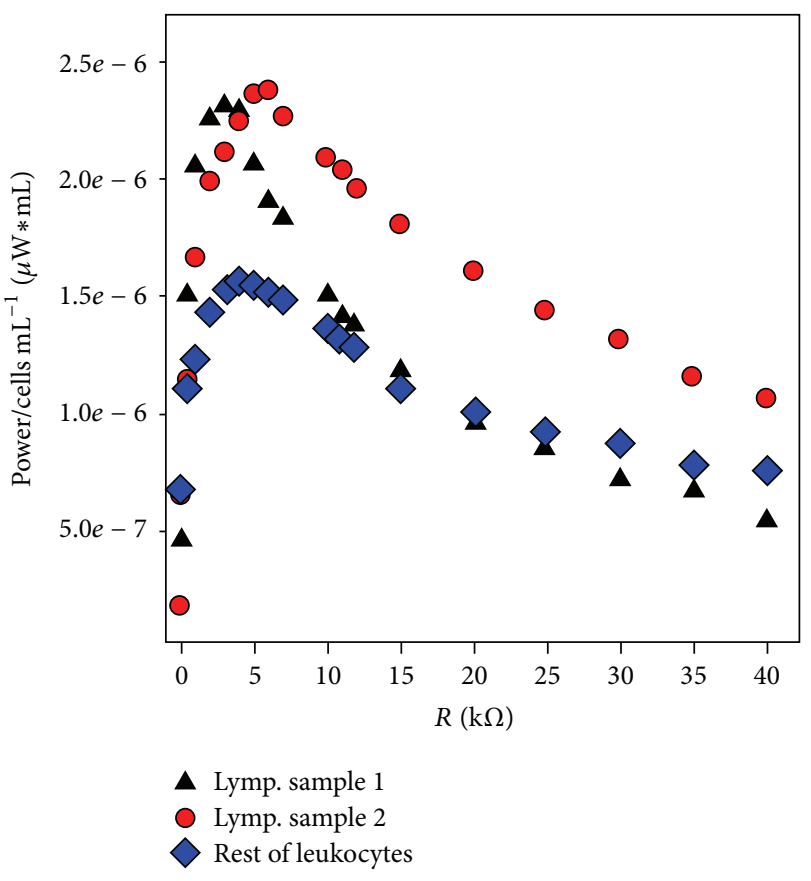

FIGURE 10: Comparison of MBFC setup power outputs/cell number under different external resistance loads obtained from lymphocytes and the rest of leukocyte family cells in plain PBS solution.

TABLE 2: Comparison of the electric output of MBFC versus implanted biofuel cells operating in vivo. The maximum power values were calculated from the original published values by taking the electrode geometric areas into account (derived from [32]).

\begin{tabular}{lccc}
\hline Animal/location & $\begin{array}{c}\text { OCP } \\
(\mathrm{mV})\end{array}$ & $\begin{array}{c}P_{\max } \\
(\mu \mathrm{W})\end{array}$ & Reference \\
\hline Rat/cremaster tissue & 140 & 0.35 & {$[32]$} \\
Rat/retroperitoneal space & 270 & 2 & {$[33]$} \\
Rat/jugular vein & 220 & 0.0095 & {$[34]$} \\
Rabbit/ear vein & 800 & 0.42 & {$[35]$} \\
Lobster/hemolymph & 550 & 160 & {$[36]$} \\
$\begin{array}{l}\text { Snail/hemolymph } \\
\text { Clam/hemolymph }\end{array}$ & 530 & 7.45 & {$[37]$} \\
$\begin{array}{l}\text { Insect } \\
\text { (Blaberus discoidalis)/ }\end{array}$ & 350 & 10 & {$[38]$} \\
abdomen & $\mathrm{n} / \mathrm{a}$ & 0.07 & {$[39]$} \\
$\begin{array}{l}\text { Human white blood cells/ } \\
\text { in vitro }\end{array}$ & 430 & (nonactivated) & $\begin{array}{c}\text { This } \\
\text { study }\end{array}$ \\
\hline
\end{tabular}

The number of dead cells counted was approximately $83 \%$ of total cell population immobilised on the electrode. Parallel to this, a culture plate containing a nonoperating anode electrode with equal number of immobilised cells was maintained under incubation conditions in an equally nonreplaced culture media for the same time length. Contrary to what was observed in the operating anode after $16 \mathrm{~h}$ only $15 \%$ of the total amount of cells immobilised on the electrode was floating dead in the solution, which points towards a viability of the cells intimately related to the MBFC operation.

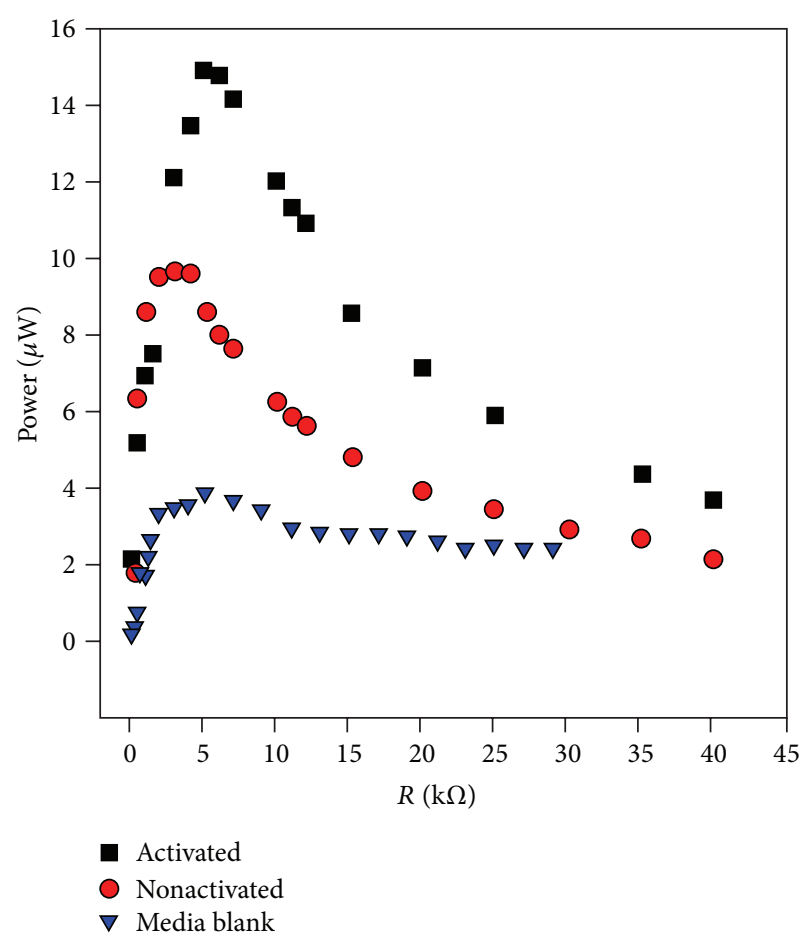

FIGURE 11: MBFC setup power outputs under different external resistance loads from PMA-activated and nonactivated lymphocytes.

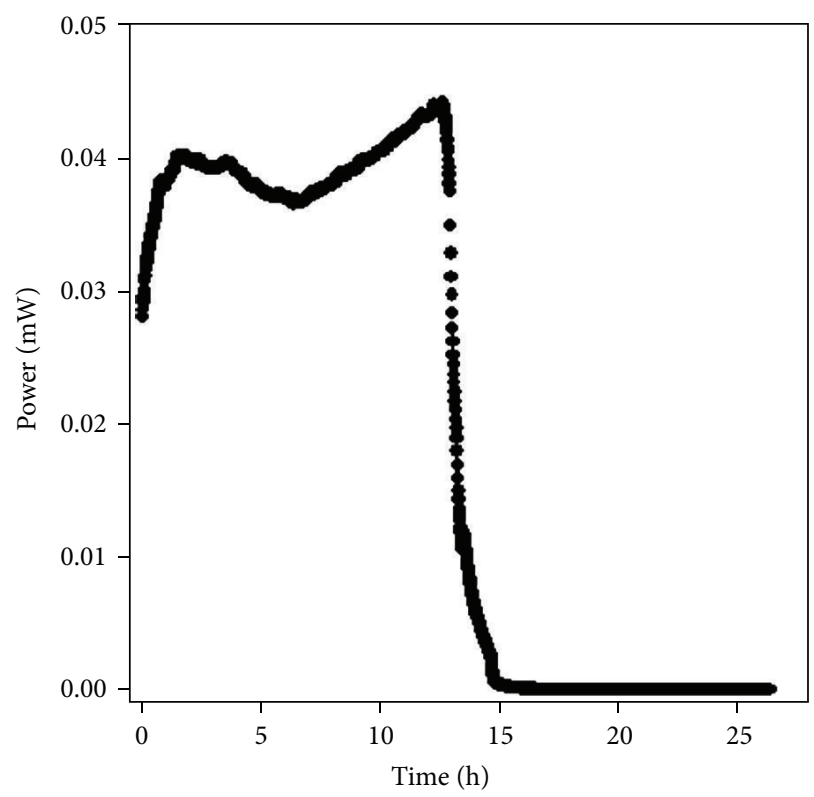

FIGURE 12: MBFC setup power evolution under constant external resistance load of $5 \mathrm{k} \Omega$.

The research on MBFC shows some promising results but required additional investigation and optimization prior to biomedical implementation. Miniaturization and biocompatibility of such a device should be studied before operating in vivo. With the aim of increasing the power output of the MBFC, we are currently working on different 
electrode materials and trying to connect the MBFCs in different configurations (e.g., in-series). Recent improvements in biofuel cell concepts in terms of carbon nanotube (CNT) compression and direct electron transfer led to high open circuit voltage, high power output, and stabilities over weeks [40]. The MBFC that produces significant level of energy at a single location could be utilized as the power source for implanted sensor devices dedicated to medical monitoring. Further optimization of MBFC could be expected to provide opportunities for other medical applications such as Multiple-lead Cardiac Resynchronisation Therapy (promising for some types of Hearth Failures) or peripheral nerve stimulations (e.g., for pain control) [41]. Future implantable medical devices such as cardiac defibrillators, deep brain neurostimulators, spinal cord stimulators, gastric stimulators, foot drop implants, cochlear implants, and insulin pumps [41] powered by implanted MBFC extracting electrical energy directly from human white blood cells are possible. The present study is one of the first steps on the long path to design bioelectronic self-powered devices, which can operate using power from human blood.

\section{Conclusion}

The present paper describes the use of human lymphocytes and leukocytes as anodic electron source for biofuel cells. Incubation and activation of cells caused an increase in power generation as it was expected. MBFC operation was tested for 10 hours with viable cells. The exact mechanism by which the cells transfer electrons to the electrode could not be elucidated.

The idea of a biofuel cell generating power on various metabolic processes occurring in human cells is very challenging. Outcome of this preliminary study reveals the potential applicability of mammalian cells in the biofuel cell system as an alternative power production method for implantable medical devices.

\section{Conflict of Interests}

The authors have no direct financial relation of any kind with any of the commercial identities mentioned in this paper.

\section{Acknowledgments}

The authors thank the Catalonian Government Agency for Administration of University and Research Grants (AGAUR) and Penn State Milton S. Hershey Medical Center for financial support and Rovira i Virgili University and Hospital Universitari Joan XXIII (both Tarragona, Spain) for the resources offered.

\section{References}

[1] T. Starner, S. Mann, B. Rhodes et al., "Augmented reality through wearable computing," Tech. Rep. 397, MIT Media Lab, Perceptual Computing Group, 1996.
[2] C. Kenneally, "Power from people breaks the hold of batteries and plugs," New York Times, 2000.

[3] M. Cooper, "Batteries not included," New Scientist, vol. 171, no. 2307, pp. 24-27, 2001.

[4] T. Starner and J.A. Paradiso, "Human generated power for mobile electronics," in Low Power Electronics Design, C. Piguet, Ed., Ch 45, pp. 1-35, CRC Press, 2004.

[5] T. Starner, "Human-powered wearable computing," IBM Systems Journal, vol. 35, no. 3-4, pp. 618-629, 1996.

[6] Y.-X. Ci, H.-N. Li, and J. Feng, "Electrochemical method for determination of erythrocytes and leukocytes," Electroanalysis, vol. 10, no. 13, pp. 921-925, 1998.

[7] H.-N. Li, Y.-X. Ci, J. Feng, K. Cheng, S. Fu, and D.-B. Wang, "The voltammetric behavior of bone marrow of leukaemia and its clinical application," Bioelectrochemistry and Bioenergetics, vol. 48, no. 1, pp. 171-175, 1999.

[8] G. A. Justin, Y. Zhang, M. Sun, and R. Sclabassi, "Biofuel cells: a possible power source for implantable electronic devices," in Proceedings of the 26th Annual International Conference of the IEEE Engineering in Medicine and Biology Society (EMBC '04), pp. 4096-4099, September 2004.

[9] G. A. Justin, Y. Zhang, M. Sun, and R. Sclabassi, "An investigation of the ability of white blood cells to generate electricity in biofuel cells," in Proceedings of the IEEE 31st Annual Northeast Bioengineering Conference, pp. 277-278, April 2005.

[10] G. Güven, P. L. Sanchez, P. Lenas, and I. Katakis, "Towards self-powered implants: electrical power from isolated human lymphocytes," in Proceedings of the 11th Transfrontier Meeting on Sensors and Biosensors, p. 15, 2006.

[11] G. A. Justin, Y. Zhang, X. T. Cui, C. W. Bradberry, M. Sun, and R. J. Sclabassi, "A metabolic biofuel cell: conversion of human leukocyte metabolic activity to electrical currents," Journal of Biological Engineering, vol. 5, article 5, 2011.

[12] J. Schrenzel, L. Serrander, B. Bánfi et al., "Electron currents generated by the human phagocyte NADPH oxidase," Nature, vol. 392 , no. 6677 , pp. 734-737, 1998.

[13] T. Matsunaga, A. Shigematsu, and N. Nakamura, "Detection of rat basophilic leukemia by cyclic voltammetry for monitoring allergic reaction," Analytical Chemistry, vol. 61, no. 22, pp. 24712474, 1989.

[14] N. Nakamura, I. Inoue, Y. Kitajima, and T. Matsunaga, "Detection of human leucocytes by cyclic voltammetry and its application to monitoring of allergic reaction," Biosensors and Bioelectronics, vol. 6, no. 5, pp. 431-437, 1991.

[15] B. V. Sarada, T. N. Rao, D. A. Tryk, and A. Fujishima, "Electrochemical oxidation of histamine and serotonin at highly borondoped diamond electrodes," Analytical Chemistry, vol. 72, no. 7, pp. 1632-1638, 2000.

[16] R. J. Sclabassi, Q. Liu, S. A. Hackworth, G. A. Justin, and M. Sun, "Platform technologies to support brain-computer interfaces," Neurosurgical Focus, vol. 20, no. 5, article E5, 2006.

[17] T. Segura, Engineering substrate-mediated gene delivery: a novel DNA delivery strategy [Doctor of Philosophy dissertation], Northwestern University, Evanston, Ill, USA, 2004.

[18] J. L. Ponchon, R. Cespuglio, F. Gonon, M. Jouvet, and M. Pujol, "Normal pulse polarography with carbon fiber electrodes for in vitro and in vivo determination of catecholamines," Analytical Chemistry, vol. 51, no. 9, pp. 1483-1486, 1979.

[19] M. Z. Wrona and G. Dryhurst, "Oxidation chemistry of 5hydroxytryptamine-1. Mechanism and products formed at micromolar concentrations," Journal of Organic Chemistry, vol. 52, no. 13, pp. 2817-2825, 1987. 
[20] M. Okochi, H. Yokouchi, N. Nakamura, and T. Matsunaga, "Electrochemical detection of allergen in small-volume whole blood using an array microelectrode: a simple method for detection of allergic reaction," Biotechnology and Bioengineering, vol. 65, pp. 480-484, 1999.

[21] D. T. Sawyer, W.R. Heineman, and J. M. Beebe, Chemistry Experiments for Instrumental Methods, John Wiley and Sons, New York, NY, USA, 1984.

[22] J. Menicucci, H. Beyenal, E. Marsili, R. A. Veluchamy, G. Demir, and Z. Lewandowski, "Procedure for determining maximum sustainable power generated by microbial fuel cells," Environmental Science and Technology, vol. 40, no. 3, pp. 1062-1068, 2006.

[23] J. Bockris and S. Srinivasan, Fuel Cells: Fundamentals and Applications, McGraw Hill, New York, NY, USA, 1969.

[24] M. Tardif, M.-J. Rabiet, T. Christophe, M.-D. Milcent, and F. Boulay, "Isolation and characterization of a variant HL60 cell line defective in the activation of the NADPH oxidase by phorbol myristate acetate," Journal of Immunology, vol. 161, no. 12, pp. 6885-6895, 1998.

[25] J. M. Robinson, P. G. Heyworth, and J. A. Badwey, "Utility of staurosporine in uncovering differences in the signal transduction pathways for superoxide production in neutrophils," Biochimica et Biophysica Acta, vol. 1055, no. 1, pp. 55-62, 1990.

[26] S. Majumdar, L. H. Kane, M. W. Rossi, B. D. Volpp, W. M. Nauseef, and H. M. Korchak, "Protein kinase C isotypes and signal-transduction in human neutrophils: selective substrate specificity of calcium-dependent $\beta$-PKC and novel calciumindependent nPKC," Biochimica et Biophysica Acta, vol. 1176, no. 3, pp. 276-286, 1993.

[27] J. T. Curnutte, R. W. Erickson, J. Ding, and J. A. Badwey, "Reciprocal interactions between protein kinase $\mathrm{C}$ and components of the NADPH oxidase complex may regulate superoxide production by neutrophils stimulated with a phorbol ester," Journal of Biological Chemistry, vol. 269, no. 14, pp. 10813-10819, 1994.

[28] J. El Benna, L. P. Faust, and B. M. Babior, "The phosphorylation of the respiratory burst oxidase component $\mathrm{p} 47$ (phox) during neutrophil activation. Phosphorylation of sites recognized by protein kinase $\mathrm{C}$ and by proline-directed kinases," Journal of Biological Chemistry, vol. 269, no. 38, pp. 23431-23436, 1994.

[29] J. El Benna, L. R. P. Faust, J. L. Johnson, and B. M. Babior, "Phosphorylation of the burst oxidase subunit p47phox as determined by two-dimensional phosphopeptide mapping: phosphorylation by protein kinase $\mathrm{C}$, protein kinase $\mathrm{A}$, and a mitogen-activated protein kinase," Journal of Biological Chemistry, vol. 271, no. 11, pp. 6374-6378, 1996.

[30] M. Southcott, K. MacVittie, and J. Halamek, "A pacemaker powered by an implantable biofuel cell operating under conditions mimicking the human blood circulatory system-battery not included," Physical Chemistry Chemical Physics, vol. 15, pp. 6278-6283, 2013.

[31] V. S. Mallela, V. Ilankumaran, and S. N. Rao, "Trends in cardiac pacemaker batteries," Indian Pacing and Electrophysiology Journal, vol. 4, no. 4, pp. 201-212, 2004.

[32] J. A. Castorena-Gonzalez, C. Foote, and K. MacVittie, "Biofuel cell operating in vivo in rat," Electroanalysis, vol. 25, pp. 15791584, 2013.

[33] P. Cinquin, C. Gondran, F. Giroud et al., "A glucose biofuel cell implanted in rats," PloS ONE, vol. 5, no. 5, Article ID e10476, 2010.
[34] F. C. Sales, R. M. Iost, M. V. Martins, M.C. Almedia, and F. N. Crespilho, "An intravenous implantable glucose/dioxygen biofuel cell with modified flexible carbon fiber electrodes," $L A b$ on A Chip, vol. 13, pp. 468-474, 2013.

[35] T. Miyake, K. Haneda, N. Nagai et al., "Enzymatic biofuel cells designed for direct power generation from biofluids in living organisms," Energy and Environmental Science, vol. 4, no. 12, pp. 5008-5012, 2011.

[36] K. MacVittie, J. Halamek, L. Halamkova et al., "From "cyborg" lobsters to a pacemaker powered by implantable biofuel cells," Energy \& Environmental Science, vol. 6, pp. 81-86, 2013.

[37] L. Halámková, J. Halámek, V. Bocharova, A. Szczupak, L. Alfonta, and E. Katz, "Implanted biofuel cell operating in a living snail," Journal of the American Chemical Society, vol. 134, no. 11, pp. 5040-5043, 2012.

[38] A. Szczupak, J. Halamek, and L. Halamkova, "Living batterybiofuel cells operating in vivo in clams," Energy and Environmental Science, vol. 5, pp. 8891-8895, 2012.

[39] M. Rasmussen, R. E. Ritzmann, I. Lee, A. J. Pollack, and D. Scherson, "An implantable biofuel cell for a live insect," Journal of the American Chemical Society, vol. 134, no. 3, pp. 1458-1460, 2012.

[40] A. Zebda, C. Gondran, A. Le Goff, M. Holzinger, P. Cinquin, and S. Cosnier, "Mediatorless high-power glucose biofuel cells based on compressed carbon nanotube-enzyme electrodes," Nature Communications, vol. 2, no. 1, article 370, 2011.

[41] A. Zebda, S. Cosnier, J.-P. Alcaraz et al., "Single glucose biofuel cells implanted in rats power electronic devices," Nature Scientific Reports, vol. 3, article 1516, 2013. 

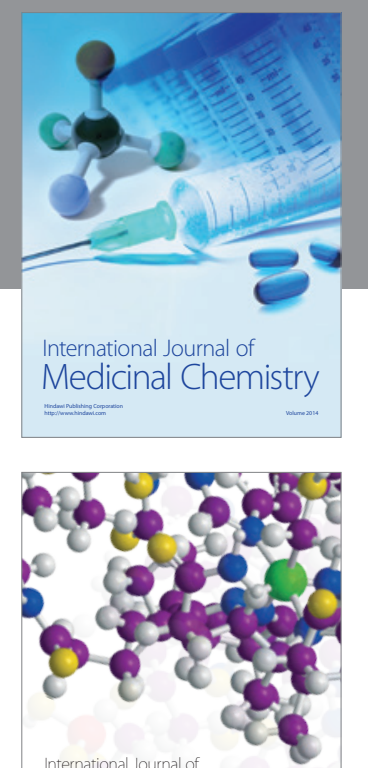

\section{Carbohydrate} Chemistry

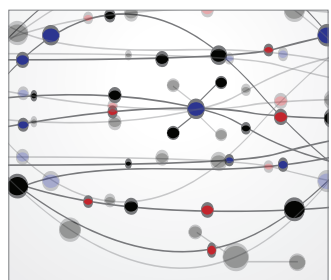

The Scientific World Journal
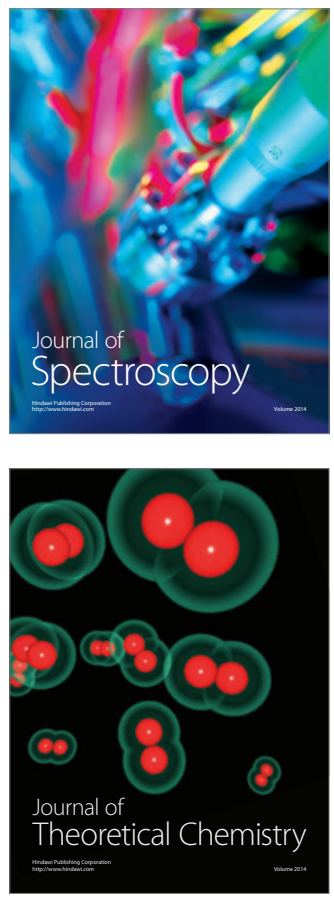
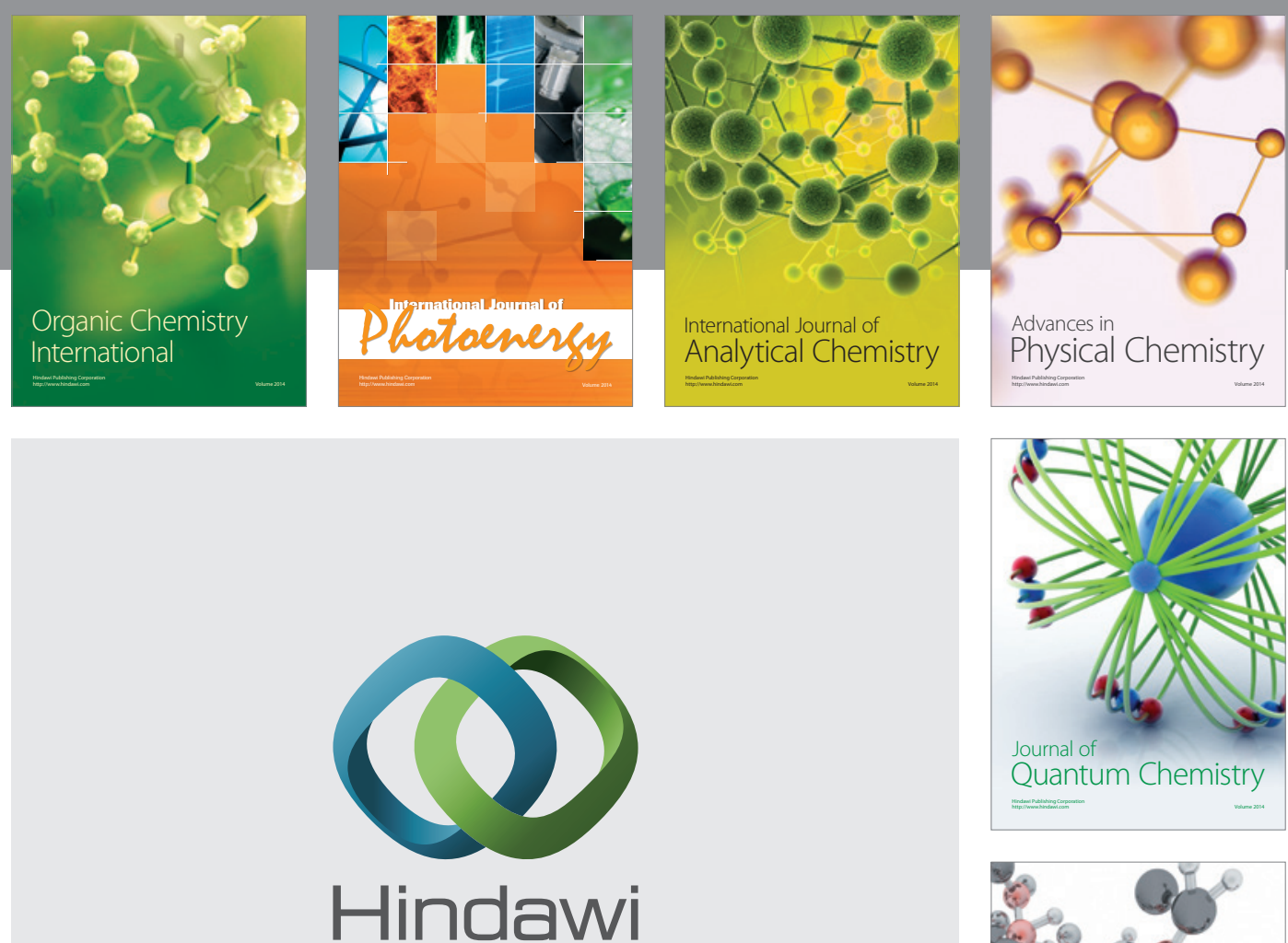

Submit your manuscripts at

http://www.hindawi.com

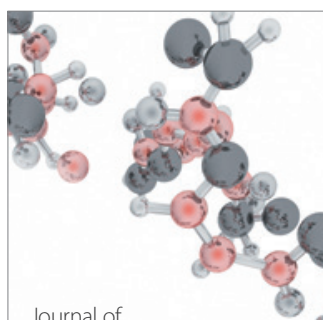

Analytical Methods

in Chemistry

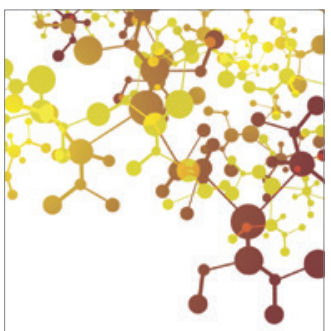

Journal of

Applied Chemistry

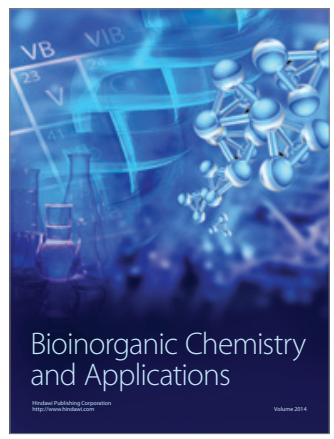

Inorganic Chemistry
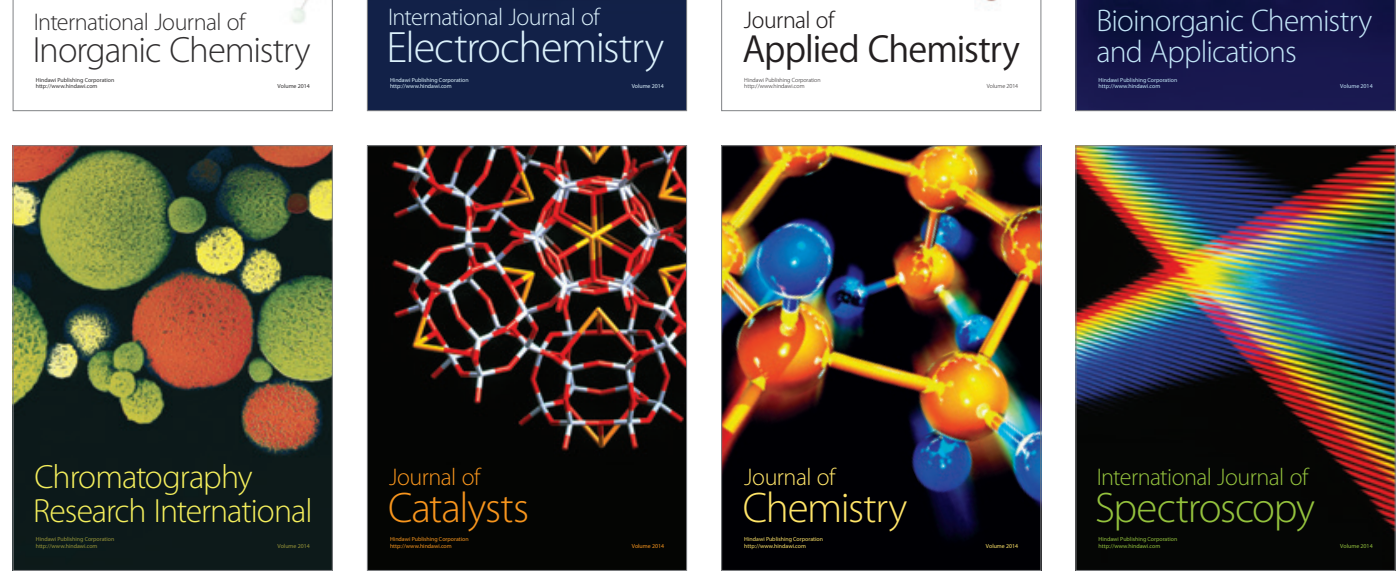